\title{
UDDER SIZE AND MILK PRODUCTION POTENTIALS OF GOATS AND SHEEP IN THE SOUTH WEST OF NIGERIA
}

\author{
J.O. AGBEDE, A.G. OLOGUN and J.A. ALOKAN \\ Department of Animal Production and Health, Federal University of Technology, P.M.B. 704, \\ Akure, Nigeria.
}

Received 22 November, 1996; Accepted 07 March, 1997.

\section{ABSTRACT}

Twelve adult lactating goats and sheep (2 to $2 \frac{1}{2}$ years old) comprising three groups of four each of West African Dwarf (WAD) goats and sheep and Yankasa ewes were used for a nine week trial. The animals kidded and lambed between January and March. During these periods, the udder sizes of the dams were measured weekly before hand milking thrice a week to determine the milk yield. Samples of the milk were analysed for their composition. The results showed that the udder size increased with increasing milk yield $(112-248 \mathrm{ml})$ up to the peak of lactation which was between weeks 3 and 4 after parturition. Thereafter it decreased in size till the end of the experiment. The coefficient of variation (CV) of the udder size was influenced by breed. Udder size was positively correlated with milk yield. Milk yields were generally low or and ranged between 39 and $70 \mathrm{ml}$ and this was dependent on the behaviour of the lactation curve. The milk protein and ash contents for the three breeds were comparable to those of the temperate breeds. Though Yankasa sheep exhibited the highest milk production potential, yet the peculiar characteristics of goat milk cannot be overlooked.

Key Words: Udder size, milk yield and composition, West African Dwarf, (WAD) Yankasa, WAD goat, sheep.

\section{INTRODUCTION}

Milk is the most complete source of nutrients for children (Pastor et al, 1993) and it is adjudged the best possible food and drink for a baby. In Nigeria, the milk consumption far out weighs its production (FAO, 1987). This may be attributed to the over dependence on cow's milk which, at present, is grossly inadequate. Literature on udder size, milk yield and composition in Nigeria deals largely with cattle (Adeneye et al, 1970; Adeneye 1989) and to a limited extent, goats (Akinsoyinu et al, 1977; Akinsoyinu, 1981) and sheep (Adu et al, 1974; Alokan, 1989). In developed countries, recent work had been reported on udder size, milk yield and composition of goats (Wang, 1989; Montaldo and Martinez-Lazano, 1993). With the current adverse effects of food crisis in Nigeria, it has now become necessary to look for possible ways $t$ f getting more nutritive feeding items notably milk, to alleviate these effects. This could possibly be achieved by using our local breeds of goats and sheep whose potentials have long been neglected as sources of dairy and dairy products.

It was on this note that the present work was designed to provide more information on udder size, milk yeild and composition of WAD goats and sheep as well as Yankasa sheep as influenced by breeds and stage of lactation.

\section{MATERIALS AND METHODS}

\section{Animais and their Managervent}

Twelve (12) lactating small ruminant dams ( 2 to $2 \frac{1}{2}$ years of age) and of unknown parity comprising three groups of four each of WAD does and ewes, and four Yankasa ewes were used for the trial. The WAD does and ewes kidded and lambed respectively between January and February, 1994 while the Yankasa ewes lambed between February and March of same year. All the animals were fitted into the experiment at three weeks after pariturition in a Completely Randomized Biock design experimentat arrangement. They were raised on a semi-intensive system of management and were always allowed to graze Giant Star grass (Cynodon nlemfuensis). Salt licks and clean 


\section{UDDER SIZE OF MILK SHEEP AND GOATS}

water were provided for the animals throughout the experiment. Veterinary care was available when required.

\section{Measurement of udder size}

Udder circumference was measured weekly throughout the experimental period that lasted 9 weeks using a one-metre length metric tape.

\section{Collection of Milk}

Hand milking was done thrice a week for all the experimental animals by $6.00 \mathrm{am}$ on the designated milking days. Prior to the day of milking, the offsprings were always separated overnight from their dams from $6.00 \mathrm{pm}$ to $6.00 \mathrm{am}$. Milk collection was done for nine weeks. Milk yields were measured using a measuring cylinder of $100 \mathrm{~cm}^{3}$ capacity immediately after collection. Portions of the total milk collected from each dam per day were stored in a deep-freeze cabinet at $-5^{\prime \prime} \mathrm{C}$ till required for analysis. Before analysis, each sample was warmed to $40^{\circ} \mathrm{C}$ to melt the fat and then cooled to $20^{\circ} \mathrm{C}:$. The desired triplicate quantities necessary for analysis were taken for each well-mixed sample. No preservatives were added.

\section{Analytical Procedure}

Milk samples were analysed for total solids, fat, crude protein ( $\mathrm{N} \times 6.38)$, lactose, and total ash. Solid-not-fat (SNF) content of the milk samples were calculated as the difference between the total solids and fat composition of the milk.

The total solids were determined by drying weighed amount of samples (approximately $10 \mathrm{ml}$ ) to constant weight at $105^{\circ} \mathrm{C}$ for 24 hours. Fat was estimated by the Gerber's method as described by Davis (1959). Protein $(N \times 6.38)$ was also determined (A.O.A.C., 1990). Lactose was assessed by the method of Barnett and Tawab (1957), the total ash was determined when a known weight of sample (approximately $5 \mathrm{ml}$ ) was evaporated to dryness and ashed in a muffle furnace at 500 $550^{\circ} \mathrm{C}$ for 2 hours. In addition, the protein-fat (P/F) ratio (Gupta and Rao, 1972) and fat/SNF ratio were calculated. Statistical evaluation was by Analysis of variance and treatment means compared by Duncan's multiple Range Test (Stecl and Torrie, 1980).

\section{RESULTS}

Table 1 shows the udder size variation and milk yield as influenced by stage of lactation. Both the udder size and milk yield were shown to increase till the second week of the experiment which was the fifth week post partum. The coefficients of variation for udder size wcre highest in WAD sheep (24.66) and least in WAD goat (18.50). The milk yield was significantly $(\mathbf{P}<0.05)$ influenced by stage of lactation and breeds.

Table 2 reveals the correlation coefficients (r) values and regression equations of udder size and milk yield. It showed that udder size and milk yield as traits can be selected together for milk production in the three breeds examined but the degree of selection will be more favoured in WAD and Yamkasa sheep breeds. Figure 1 shows the lactation curves for the three breeds examined. It indicated that though milk yield curves were highest at week 4 of the experiment, the curves varied with different breeds. Table 3 shows the mean milk composition and their interrelationships. It showed that all the compositions and the interrelationships calculated were not significantly $(P>0.05)$ influenced by the breed effects expect for ash contents.

\section{DISCUSSION}

The udder sizes of the three breeds used in this study increased with increasing milk yield up to the peak of lactation which was between 3 and 4 weeks after parturition before it decreased in size till the end of the experiment. This agreed with other reports (Rugina et al, 1982; Perez et al, 1983). The CV was highest in WAD sheep followed by Yankasa sheep and WAD goat. This suggests that udder size may be influenced by breed and that breeds could respond positively to selection in udder size in that order. The significant correlations between udder size and milk yield observed here corroborate the report of Perez et al, (1983) and Odabasioglu, (1985). This may be due to the fact that 
TABLE 1: UDDER SIZE AND MILK YIELD OF GOATS AND SHEEP AS INFLUENCED BY STAGE OF LACTATION

\begin{tabular}{|c|c|c|c|c|c|c|}
\hline \multicolumn{3}{|c|}{$\begin{array}{l}\text { Week of } \\
\text { Sampling }\end{array}$} & \multicolumn{2}{|c|}{ WAD goat } & \multicolumn{2}{|c|}{ Yankasa Sheep } \\
\hline & $\begin{array}{l}\text { Udder size } \\
\mathrm{cm}\end{array}$ & $\begin{array}{l}\text { Milk yield } \\
\mathrm{ml}\end{array}$ & $\begin{array}{l}\text { Udder size } \\
\qquad \mathrm{cm}\end{array}$ & $\begin{array}{l}\text { Milk yield } \\
\quad \text { ml }\end{array}$ & $\begin{array}{l}\text { Udder size } \\
\mathrm{cm}\end{array}$ & $\begin{array}{l}\text { Milk Yield } \\
\quad \mathrm{ml}\end{array}$ \\
\hline 3 & 17.0 & 112 & 26.2 & 143 & 27.1 & 127 \\
\hline 4 & 22.3 & $\$ 43$ & 29.1 & 198 & 30.9 & 248 \\
\hline 5 & 21.9 & 123 & 24.9 & 175 & 28.1 & 188 \\
\hline 6 & 21.2 & 97 & 24.1 & 133 & 27.5 & 163 \\
\hline 7 & 21.2 & 80 & 23.0 & 148 & 26.9 & 163 \\
\hline 8 & 20.0 & 80 & 22.0 & 114 & 25.3 & 118 \\
\hline 9 & 17.7 & 60 & 18.5 & 88 & 19.0 & 98 \\
\hline 10 & 15.5 & 78 & 15.3 & 53 & 18.7 & 85 \\
\hline 11 & 12.0 & 65 & 12.5 & 39 & 15.3 & 70 \\
\hline Mean & 18.76 & $93.11^{b}$ & 21.74 & $121.22^{a}$ & 24.31 & $140^{a}$ \\
\hline S.Dev. & 3.47 & 27.87 & 5.36 & 53.25 & 5.29 & 56.31 \\
\hline C.V. & 18.50 & & 24.66 & & 21.76 & \\
\hline
\end{tabular}

WAD $=$ West African Dwarf

$\mathrm{CV}=$ Coefficient of Variation

a,b, - means aløng the same row with any unidentical superscripts differ significantly $(P<0.05)$

TABLE 2: CORRELATION COEFFICIENTS (R) AND REGRESSION EQUATIONS OF UDDER SIZE AND MILK YIELD OF GOATS AND SHEEP

\begin{tabular}{cll}
\hline Milk yield versus udder size & r values & Regression Equations \\
\hline WAD goat & 0.60 & $\mathrm{Y}=11.71+0.08 \mathrm{X}$ \\
WAD sheep & 0.98 & $\mathrm{Y}=9.99+0.10 \mathrm{X}$ \\
WAD Yankasa & 0.89 & $\mathrm{X}=12.55+0.89 \mathrm{X}$ \\
\hline
\end{tabular}

$\mathrm{Y}=$ Udder size variation; $\quad \mathrm{X}=$ Milk yield

TABLE 3: VARIATION IN MILK COMPOSITION AND INTERRELATIONSHIP BETWEEN MILK CONSTITUENTS OF GOATS AND SHEEP.

\begin{tabular}{llll}
\hline Parameters & WAD goat & WAD Sheep & Yankasa \\
\hline Total Solid (\%) & $15.54 \pm 2.05$ & $14.86 \pm 1.48$ & $15.69 \pm 1.00$ \\
Solid Not Fat (SNF) \% & $11.32 \pm 2.16$ & $11.28 \pm 1.81$ & $11.66+1.47$ \\
Protein \% & $4.89 \pm 1.03$ & $4.90 \pm 0.68$ & $5.06 \pm 0.38$ \\
Fat \% & $4.22 \pm 1.07$ & $3.58 \pm 1.38$ & $4.03 \pm 1.02$ \\
Lactose \% & $5.66 \pm 1.36$ & $5.57 \pm 1.68$ & $5.74 \pm 1.27$ \\
Ash \% & $0.78^{\mathrm{b}} \pm 1.07$ & $0.81^{\mathrm{ab}} \pm 0.04$ & $0.84^{\mathrm{a}} \pm 0.05$ \\
Fat/SNF ratio & $0.39 \pm 0.15$ & $0.34 \pm 0.18$ & $0.36 \pm 0.12$ \\
Protein/Fat ratio & $1.23 \pm 0.39$ & $1.59 \pm 0.71$ & $1.36 \pm 0.51$ \\
\hline
\end{tabular}

WAD = West African Dwarf

$\mathrm{a}, \mathrm{b}=$ means along the same row with unidentical superscripts differ significantly $(\mathrm{P}<0.05)$. 
parturition necessitates the needs to feed the new born. Thus, there is increased blood flow with nutrients to the udder; and this may lead to increase in udder size and milk synthesis and production. By implication it may be possible to predict milk yield from the measurement of udder size using regression equations.

The milk yields of the breeds examined were low when compared with the temperate breeds (Wallace, 1948; Thomson and Thomsom, 1953; Badamana, 1990). This could be due to the fact that these animals are of small body size especially the WAD goats and the animals have not been selected for milk production. The mean milk yields which were influenced $(P<0.05)$ by stage of lactation and breed agree with the reports of Akinsoyinu et al (1977) and Pastor et al (1993). The lactation curve is similar to the one reported (Ologun and Oshodi, 1994) for Yankasa sheep. Yankasa sheep with the mean milk yield of $140 \mathrm{ml}$, though very low, appeared to show the greatest milk yeild. With the mean yield, coupled with the bizger body size, these animals might be genetically superior to WAD goat and sheep. Further comparative studies of the milk yield among these animals using larger numbers are suggested.

The average percent total solid, SNF observed in this study were lower than those reported (Akinsoyinu et al, 1977; Alokan, 1989) for goats and sheep respectively, but higher than those reported elsewhere (Devendra, 1980; Koushik and Gupta, 1989 and Nyakalo et al, 1990). While the average percentage crude protein content for the three breeds were comparable to those reported (Nyakalo et al, 1990), fat and lactose contents of the milk were lower than those reported elsewhere (Akinsoyinu et al, 1977; Devendra, 1980 ) and also higher than reported by Koushik and Gupta (1989).

The percentage ash contents for the three breeds examined were significantly $(P<0.05)$ influenced by breeds. This corroborated the report by Jenness (1986). The observed ash contents were comparable to those of Akinsoyinu et al, (1977); Devendra, (1980);
Koushik and Gupta, (1989) and Nyakalo et al, (1990) but lower than those reported (Alokan, 1989). The Fat/SNF ratios obtained were lower than the 0.54 reported by Koushik and Gupta (1989). This thus indicates that these three breeds have little quantity of fat in their milk. Conversely, the protein/fat ratios were all higher than the values reported (Koushik and Gupta, 1989). Their milk protein contents were therefore high with attendant lower fat content. The indication of this is that more protein will be consumed per unit volume than fat in their milk.

Generally, all the compositions measured were not significantly influenced $(P<0.05)$ by breed except the ash content. From this study, it appears that Yankasa sheep may have some genctic superiority which favour milk production better than in the remaining two other breeds, yet goat milk has its own peculiar qualities that are nutritionally and medically supcrior to sheep or cow's milk (Egwu et al, 1995). Therefore, improvement can still be achieved in the milk yields and composition of the three breeds with the introduction of good management practices such as selection and cross breeding, provision of good nutrition, to mention but a few.

\section{REFERENCES}

ADENEYE, J.A. (1989). Variation in yield and composition of milk from different udder quarters of lactating White Fulani cattle in a tropical environment. Nig. J. Anim. Prod. 16:8-15.

ADENEYE, J.A. OYENUGA, V.A. and OLALOKU, E.A. (1970). Preliminary findings on the composition of White Fulani cattle Nig. J. Sci. 4: 181 - 186

ADU, I.F., OLALOKU, E.A. and OYENUGA, V.A. (1974). The effects of energy intake during late pregnancy and lamb birth weights and lactation of Nigerian Dwarf sheep. Nig. $J$, Anim. Prod. 1 (2): 151 - 161.

AKINSOYINU, A.O., MBA, A.U. AND OLUBAJO, F.O. (1977) Studies of milk yield and composition of the West African Dwarf goats in Nigeria. J. Dairy Research 14: $57-62$ AKINSOYINU, AO: (1981). Calcium and phosphorous in milk and blood serum of the 
lactating Red. Sokoto Goats J. Dairy Reseanch, 48: 509 - 511.

ALOKAN, J.A. (1989). Performance of West African Dwarf sheep fed corn-corn cob diets supplemented to different protein levels. (Ph.D Thesis) Univ. of Ibadan, Nigeria. 305pp.

A.O.A.C. (1990). Official methods of Analysis. Association of Official Analytical Chemist. Washington, D.C.

BADAMANA, M.S. (1990). The effect of level of protein in the concentrates on the performance of diary goats. Proceedings of the 8th SR - CRSP Scientific Workshop - Small numinants 7 - 8th March 1090 ILRAD, Nairobi - Kenya pp 22 - 30.

BARNETT, A.J.G. AND TAWAB, G.A. (1957). Rapid method for the determination of lactose in milk and cheese.J. Sci. Ed. Agric. 8: 437 - 441.

DAVIS, J.G. (1959). Milk Secretion. The laboratory control of milk (2nd Ed.). Dairy Industries, London

DEVENDRA, C. (1980). Milk production in goats compared to buffaloes and cattle in the humid tropics J. Dairy Sci. 63: 1755- 1767.

EGWU, G.O. ONYEYILI, P.A., CHIBUZO, G.A. and AMEH, J.A. (1995). Improved productivity of goats and utilization of goat milk in Nigeria. Small Rumin. Res. 16: 195 201.

F.A.O. (1987). Crossbreeding Bos taurus for milk production in the tropics. Vol. $68: 1$, Rome, Italy.

GUPTA, M.P. and RAO, Y.S. (1972). Chemical quality of Market Khurchan. Indian J. Dairy Sci. 25: $70-72$

JENNESS, R. (1986). Symposium - species variation in mammary gland function, lactational performance of various mammalian species. J. Dairy Sci, 69:869-885.

KOUSHIK, M.R. and GUPTA, M.P. (1989). Variation in chemical composition and inter-relationship between certain constituents of goat milk. Indian J. Anim. Sci. 59(7):905-907.

$\begin{array}{crr}\text { MONTALDO, } & \text { H. } & \text { AND } \\ \text { MARTINEZ-LOZANO, } & \text { F.J. } & (1993) \text {. }\end{array}$ Phenotypic relationships between udder and milking characteristics, milk production and California mastitis tests in goats. Small
Rumin. Res. 12: 329-338.

NYAKALO, S., BADAMANA, M.S. and WANYIOKE, M (1990). The effect of increasing chicken manure levels in supplemental diets for lactating Galla goats on milk composition. Proceedings of the 8th SR - CRSP Scientific Workshop Small Ruminants 7-8th March, 1990ILRAD Nairobi - Kenya pp. 221 - 231.

ODABASIOGLU, F. (1985). Milk Production characteristics of Red Karaman, While Karaman and Awassi Ewes. Anim. breeding Abstr. 54 (7): 4440.

OLOGUN, A.G. AND OSHODI, O.T. (1994). Milkability, Milk yield and composition of Yankasa ewes in a humid tropical environment. A preliminary study. Proceeding of the 31st Annual National Conference of the Nigerian Veterinary Association, at the Federal Univ. of Technology, Akure, Nigeria. 24th - 28th Oct., 1994. In press.

PASTOR PEDRAZA, MARISELA PERALTA AND RAUL PEREZGROVAS (1993). An alternative source of milk. ILELA Newsletter 1: 8-9.

PEREZ LINARES, J., COMEZ GIL, J.L. and GARCIA LAPEZ, J. (1983) Comparison of methods for milking Mancha ewes Anim. breeding Abstr. 53, (10): 6373.

RUGINA, L., COSTACHESEU, E; PLAMODEALA, C. AND MOCANU E. (1982). Morphological and physiological characteristics of the mammary gland of Transy Ivarian Merino ewes at the IASI experiment station. Anim. breeding Abstr. 54 (8): 5204.

STEEL, R.G.D. and TORRIE, J.H. (1980). Principles and Procedures of Statistics. A Biometical Approach 2nd edn. McGraw-Hill Book Company Inc.. New York. pp. 137 - 171.

THOMSON, W. and THOMSON, A.M. (1953). Effect of diet on milk yield of the ewe and growth of her lamb. Brit. J. Nutr. 7: 263 - 271.

WALLACE, L.R. (1948). Growth of lambs before and after birth in relation to the level of nutrition. J. Agric. Sci. Camb 38: 93 - 153.

WANG, P.Q. (1989). Udder characteritics in Toggenburg dairy goats Small Rumin. Res. 2: $181-190$. 